\title{
The secretions of oviduct epithelial cells increase the equine in vitro fertilization rate: are osteopontin, atrial natriuretic peptide $A$ and oviductin involved?
}

\author{
Sylvie Mugnier 1,2,3,4, Morgane Kervella1,2,3,4, Cécile Douet 1,2,3,4, \\ Sylvie Canepa ${ }^{1,2,3,4}$, Géraldine Pascal1,2,3,4, Stefan Deleuze ${ }^{5}$, Guy Duchamp ${ }^{6}$, \\ Philippe Monget ${ }^{1,2,3,4}$ and Ghylène Goudet*1,2,3,4
}

\begin{abstract}
Address: ${ }^{1}$ INRA, UMR85, Physiologie de la Reproduction et des Comportements, F-37380 Nouzilly, France, ${ }^{2}$ CNRS, UMR6175, F-37380 Nouzilly, France, ${ }^{3}$ Université François Rabelais de Tours, F-37041 Tours, France, ${ }^{4}$ Haras Nationaux, F-37380 Nouzilly, France, ${ }^{5}$ Faculté de Médecine Vétérinaire, Département des Sciences Cliniques - Clinique Equine, Université de Liège, B-4000 Liège, Belgium and ' INRA, UE1297 Unité Expérimentale de Physiologie Animale de l'Orfrasière, F-37380 Nouzilly, France

Email: Sylvie Mugnier - sylvie.mugnier@tours.inra.fr; Morgane Kervella - minibout37@yahoo.fr; Cécile Douet - cecile.douet@tours.inra.fr; Sylvie Canepa - sylvie.canepa@tours.inra.fr; Géraldine Pascal - geraldine.pascal@tours.inra.fr; Stefan Deleuze - S.Deleuze@ulg.ac.be; Guy Duchamp - guy.duchamp@tours.inra.fr; Philippe Monget - philippe.monget@tours.inra.fr;

Ghylène Goudet* - ghylene.goudet@tours.inra.fr

* Corresponding author
\end{abstract}

Published: 19 November 2009

Reproductive Biology and Endocrinology 2009, 7:129 doi:10.1 186/1477-7827-7-129

This article is available from: http://www.rbej.com/content/7/I/I29

(C) 2009 Mugnier et al; licensee BioMed Central Ltd.

This is an Open Access article distributed under the terms of the Creative Commons Attribution License (http://creativecommons.org/licenses/by/2.0), which permits unrestricted use, distribution, and reproduction in any medium, provided the original work is properly cited.

\begin{abstract}
Background: Oviduct epithelial cells (OEC) co-culture promotes in vitro fertilization (IVF) in human, bovine and porcine species, but no data are available from equine species. Yet, despite numerous attempts, equine IVF rates remain low. Our first aim was to verify a beneficial effect of the OEC on equine IVF. In mammals, oviductal proteins have been shown to interact with gametes and play a role in fertilization. Thus, our second aim was to identify the proteins involved in fertilization in the horse.
\end{abstract}

Methods \& results: In the first experiment, we co-incubated fresh equine spermatozoa treated with calcium ionophore and in vitro matured equine oocytes with or without porcine OEC. We showed that the presence of OEC increases the IVF rates. In the subsequent experiments, we coincubated equine gametes with OEC and we showed that the IVF rates were not significantly different between I) gametes co-incubated with equine vs porcine OEC, 2) intact cumulus-oocyte complexes vs denuded oocytes, 3) OEC previously stimulated with human Chorionic Gonadotropin, Luteinizing Hormone and/or oestradiol vs non stimulated OEC, 4) in vivo vs in vitro matured oocytes.

In order to identify the proteins responsible for the positive effect of OEC, we first searched for the presence of the genes encoding oviductin, osteopontin and atrial natriuretic peptide A (ANP $A$ ) in the equine genome. We showed that the genes coding for osteopontin and ANP A are present. But the one for oviductin either has become a pseudogene during evolution of horse genome or has been not well annotated in horse genome sequence. We then showed that osteopontin and ANP A proteins are present in the equine oviduct using a surface plasmon 
resonance biosensor, and we analyzed their expression during oestrus cycle by Western blot. Finally, we co-incubated equine gametes with or without purified osteopontin or synthesized ANP A. No significant effect of osteopontin or ANP A was observed, though osteopontin slightly increased the IVF rates.

Conclusion: Our study shows a beneficial effect of homologous and heterologous oviduct cells on equine IVF rates, though the rates remain low. Furthers studies are necessary to identify the proteins involved. We showed that the surface plasmon resonance technique is efficient and powerful to analyze molecular interactions during fertilization.

\section{Background}

The oviduct is an essential organ in reproductive biology. This organ supports gamete transport, maturation, capacitation, fertilization, early embryonic growth and embryo transport to the uterus [1]. Oviduct fluid is comprised of a serum filtrate, follicular fluid and oviduct-specific secretory products from secretory cells [2]. The secretion of oviduct secretory cells increases during the follicular phase under oestrogen and LH stimulation [3,4]. Some studies show that oviduct epithelial cells (OEC) co-culture promotes in vitro production of embryos in human $[5,6]$, bovine[7-9], porcine $[10,11]$, deer $[12,13]$ and dromedary [14]. Moreover, the oviduct proteins have been shown to interact with gametes and to improve efficiency of in vitro fertilization (IVF) in porcine $[10,15]$, bovine [9] and human [16]. Some of these proteins have been identified: osteopontin [17-19] in bovine and porcine, Atrial Natriuretic Peptide A (ANP A), [20-22] and oviductin [[9,23] for review; $[10]]$ in bovine, porcine and human.

In the equine, numerous attempts to establish an efficient IVF technique were performed during the last decades [2427]. However, reported fertilization rates range from $0 \%$ to $60 \%$ which are lower than the IVF rates of 90 to $95 \%$ observed in porcine [[28,29] for review, [30] for review, [31] for review], bovine [[32] for review], caprine [33-36] or ovine species $[37,38]$. No repeatable equine IVF technique is available yet. In equine species, the co-culture with OEC improves the capacitation of spermatozoa evaluated by chlortetracycline staining and zona binding $[39,40]$ or intracellular calcium concentration and acrosome reaction $[41,42]$. It also improves the selection of spermatozoa determined by the percentage of motile and morphologically normal spermatozoa attached to oviductal cells $[43,44]$. The in vivo fertilization of in vitro matured oocytes in the oviduct of mare predicts an influence of oviduct in the equine fertilization [45-47]. However, IVF in co-culture with OEC has never been investigated in this species. In addition, the role of oviductal secretion on the equine fertilization is unknown.

We hypothesized that the secretion of oviduct cells could improve equine IVF. The aims of our study were 1 ) to verify the beneficial effect of the oviduct cells and fluid on equine IVF, and 2) to identify the proteins responsible for this positive effect.

\section{Methods}

All chemicals were purchased from Sigma-Aldrich (St Quentin Fallavier, France) unless otherwise indicated. All procedures described within were approved by the "Institut National de la Recherche Agronomique" Animal Care and Use Committee, and were performed in accordance with the Guiding Principles for the Care and Use of Laboratory Animals.

\section{General methods}

Preparation of equine and porcine oviduct epithelial vesicles and monolayers

Porcine oviducts were collected from slaughtered Meishan gilts from our experimental pigsty (UE1297 Unité Expérimentale de Physiologie Animale de l'Orfrasière, Nouzilly, France). Adult cyclic gilts received a daily dose of $5 \mathrm{ml}$ Regumate $(20 \mathrm{mg} /$ gilt/day of Altrenogest, Intervet S.A., Angers, France) per os during 18 days. An intravenous injection of human Chorionic Gonadotropin (hCG, Chorulon $^{\circledast}, 500$ IU/gilt, Intervet S.A.) was performed 3 days later. Gilts were slaughtered 46 hours after hCG injection ( 6 hours after ovulation) and the two oviducts were immediately collected.

Equine oviducts ipsilateral to ovulation were collected from slaughtered adult cyclic Welsh pony mares from our experimental stud (UE1297 Unité Expérimentale de Physiologie Animale de l'Orfrasière, Nouzilly). Ovarian activity was assessed by routine rectal ultrasound scanning. An intravenous injection of $15 \mathrm{mg}$ of Crude Equine Gonadotropin (CEG, [48]) was performed at the end of the follicular phase, when the largest follicle reached $33 \mathrm{~mm}$ in diameter, to induce ovulation. Then, ovarian activity was assessed every two hours from 32 hours post induction to ovulation. Mares were slaughtered 6 hours after ovulation and the oviduct ipsilateral was immediately collected.

Equine and porcine oviducts were transported to the laboratory within a few minutes in Tissue Culture Medium 199 with Hepes and Earls's salts (TCM199-Hepes) with 80 $\mu \mathrm{g} \mathrm{ml} \mathrm{m}^{-1}$ gentamycin at $37^{\circ} \mathrm{C}$. 
The equine or porcine oviduct epithelial cells were prepared according to Locatelli et al. [13]. The oviducts were dissected free from surrounding tissues and washed. The oviduct fluid and epithelial cells were expelled by gentle squeezing using a sterile microscope slide in a Petri dish. Resulting epithelium fragments were washed three times in TCM199-Hepes with $80 \mu \mathrm{g} \mathrm{ml}^{-1}$ gentamycin. These fragments formed vesicles which were cultured in culture medium containing Tissue Culture Medium 199 with Earls's salts (TCM199) with 10\% (v/v) Fetal Calf Serum (FCS) and $40 \mu \mathrm{g} \mathrm{ml}^{-1}$ gentamycin in an incubator (at $38.5^{\circ} \mathrm{C}$ in an atmosphere of $5 \% \mathrm{CO}_{2}$ in air in $100 \%$ humidity). Vesicles were cultured either for 24 hours in 35 $\mu \mathrm{l}$ drops of culture medium covered with $500 \mu \mathrm{l}$ mineral oil or for 7 days in $500 \mu \mathrm{l}$ of culture medium with renewal of the culture medium every 48 hours. After 7 days, only confluent cell monolayers containing epithelial cells and cells with ciliary activity, free of fibroblasts (elongated cells) and bacteria, were used for the experiments.

\section{Preparation of equine in vitro matured oocytes}

Equine immature cumulus-oocyte complexes (COCs) were collected from slaughtered mares. Ovaries were obtained in local slaughterhouses immediately after females were killed and transported to the laboratory within 2 hours in $0.9 \%(\mathrm{w} / \mathrm{v}) \mathrm{NaCl}$ at $32-38^{\circ} \mathrm{C}$. COCs were collected with the aspiration procedure as previously described by Mugnier et al. [49]. Immature COCs were washed once in washing medium containing TCM199Hepes supplemented with $40 \mu \mathrm{g} \mathrm{ml}^{-1}$ Bovine Serum Albumin (BSA, fatty acid free) and $25 \mu \mathrm{g} \mathrm{ml}^{-1}$ gentamycin and once in maturation medium containing TCM199 supplemented with $20 \%(\mathrm{v} / \mathrm{v})$ FCS and $50 \mathrm{ng} \mathrm{ml}^{-1}$ epidermal growth factor [50]. COCs were cultured in groups of 10 to 25 oocytes for 26 to 30 hours in $500 \mu$ of maturation medium in an incubator. After in vitro maturation (IVM), only oocytes showing an intact oolemma were kept.

\section{Recovery of equine in vivo matured oocytes}

Equine in vivo matured COCs were collected by transvaginal ultrasound-guided aspiration in standing mares from our experimental stud as previously described by Mugnier et al. [51].

\section{Preparation of equine semen}

Semen was collected from two Welsh pony stallions (A and B) from our experimental stud using an artificial vagina. Sperm cells from each stallion were prepared separately as previously described by Palmer et al. [24]. Briefly, sperm was collected, filtered, diluted to $25 \times 10^{6}$ spermatozoa $\mathrm{ml}^{-1}$ in Hank's solution supplemented with $1 \%(\mathrm{w} / \mathrm{v})$ BSA and $20 \mathrm{mmol} \mathrm{l}^{-1}$ Hepes (HHBSA) at pH 7.1, and incubated at $37^{\circ} \mathrm{C}$ for 30 minutes in anaerobic conditions. Spermatozoa were then treated with $6 \mu \mathrm{mol} \mathrm{l^{-1 }}$ of calcium ionophore A23187 (free acid) at $37^{\circ} \mathrm{C}$ for $5 \mathrm{~min}$ utes [52], centrifuged for 3 minutes at $500 \times \mathrm{g}$ and resuspended in HHBSA medium $\left(25 \times 10^{6}\right.$ spermatozoa $\left.\mathrm{ml}^{-1}\right)$. The motility was visually evaluated using an inverted epifluorescence microscope (Olympus, IMT-2, Paris, France).

\section{Assessment of equine in vitro fertilization (IVF) rates}

After 24 hours of male and female gametes co-incubation, oocytes were washed by aspiration in and out of a glass pipette in Dulbecco's Phosphate Buffered Saline solution (DPBS, Dulbecco A, Paris, France) to remove spermatozoa attached to the zona pellucida. Oocytes were fixed in $2 \%$ $(\mathrm{v} / \mathrm{v})$ paraformaldehyde in DPBS overnight at $4{ }^{\circ} \mathrm{C}$,

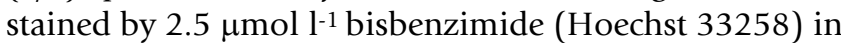
DPBS:Glycerol $(3: 1, \mathrm{v} / \mathrm{v})$, mounted on microscope slides, and observed under an inverted epifluorescence microscope. Normal fertilization was defined by the presence of two polar bodies and two pronuclei. The IVF rate was calculated as the ratio of fertilized oocytes out of mature oocytes (oocytes in metaphase II, activated and fertilized oocytes) as previously described by Mugnier et al. [51].

\section{Statistical analysis}

For each experiment, due to the limited number of oocytes available on a single day, two to three replicates were performed. The IVF rates were compared between groups of oocytes in each experiment using chi-square analysis. When the number of oocytes in a group was too low for the chi-square test, the Fisher's exact test was used. Differences were considered statistically significant at $\mathrm{P} \leq$ 0.05 .

\section{Experiment I: Influence of porcine vesicles and cell monolayers on equine IVF}

We tested the influence of porcine vesicles in the first trial (three replicates) and the influence of porcine cell monolayers in the second trial (two replicates).

After in vitro maturation, all equine COCs were mechanically denuded in $500 \mu \mathrm{l}$ washing medium and washed in culture medium. Oocytes ( 10 to 20 per group) were coincubated with or without vesicles or cell monolayers, depending on the trial, for 2 to 3 hours in an incubator. Spermatozoa (final concentration of $2.5 \times 10^{6}$ cells $\mathrm{ml}^{-1}$ ) from stallion A or B were added with oocytes. Gametes were co-incubated in a final volume of $50 \mu$ in the first trial and $515 \mu \mathrm{l}$ in the second trial, for 24 hours in an incubator.

\section{Experiment 2: Influence of equine vs porcine vesicles and cell monolayers on equine IVF}

After in vitro maturation, all equine COCs were denuded and washed. Oocytes (10 to 20 per group) were co-incu- 
bated with equine or porcine vesicles or with equine or porcine cell monolayers for 2 to 3 hours in an incubator.

Spermatozoa (final concentration of $2.5 \times 10^{6}$ cells ml $^{-1}$ ) from stallion A or B were added with oocytes. Gametes were co-incubated in a final volume of $50 \mu \mathrm{l}$ with porcine or equine vesicles or $515 \mu \mathrm{l}$ with porcine or equine cell monolayers, for 24 hours in an incubator. This experiment was repeated once with equine vesicles (stallion A), four times with equine cell monolayers (twice with stallion $\mathrm{A}$ and twice with stallion $\mathrm{B}$ ), five times with porcine vesicles and cell monolayers (twice with stallion $\mathrm{A}$ and three times with stallion $B$ ).

\section{Experiment 3: Influence of equine cumulus cells on equine IVF}

After in vitro maturation, half of the COCs were mechanically denuded in the washing medium and half were kept intact.

Denuded oocytes or COCs (10 to 20 per group) were rinsed in the culture medium and co-incubated with porcine vesicles for 2 to 3 hours in an incubator.

Spermatozoa (final concentration of $2.5 \times 10^{6}$ cells ml-1) were added with COCs or denuded oocytes. Gametes were co-incubated in a final volume of $50 \mu \mathrm{l}$ for 24 hours in an incubator. This experiment was repeated once with stallion $\mathrm{A}$ and once with stallion $\mathrm{B}$.

\section{Experiment 4: Influence of hormonal stimulation of porcine oviduct cells on equine IVF}

We compared the IVF rates after co-incubation of equine gametes with porcine vesicles or cell monolayers stimulated or not by hormones. Eight trials were performed: vesicles and cell monolayers were stimulated with Luteinizing Hormone (LH), human Chorionic Gonadotropin (hCG), Estradiol-17 beta $\left(\mathrm{E}_{2}\right)$ or $\mathrm{LH}$ and $\mathrm{E}_{2}$. Each trial was repeated once with stallion $A$ and once with stallion $B$. The hormones used were: 1) $0.1 \mu \mathrm{g} \mathrm{ml}^{-1}$ of porcine $\mathrm{LH}$ (kindly donated by J-F Beckers, University of Liege, Belgium), 2) $150 \mathrm{mIU} \mathrm{ml}^{-1}$ of hCG, 3) $1 \mu \mathrm{g} \mathrm{ml}^{-1}$ Estradiol-17 beta $\left(E_{2}\right)$ or 4$)$ the association of $\mathrm{LH}\left(0.1 \mu \mathrm{g} \mathrm{ml}^{-1}\right)$ and $\mathrm{E}_{2}$ $\left(1 \mu \mathrm{g} \mathrm{ml}^{-1}\right)$. The hormones were added to the culture medium of the oviduct cells 24 hours before gametes coincubation.

In each trial, after in vitro maturation, all equine COCs were denuded and washed. Oocytes (10 to 20 per group) were co-incubated for 2 to 3 hours with oviduct cells stimulated or not in an incubator. Spermatozoa (final concen-

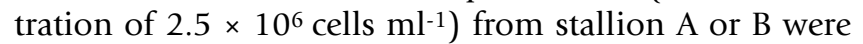
added with oocytes. Gametes were co-incubated in a final volume of $50 \mu \mathrm{l}$ with porcine vesicles or $515 \mu \mathrm{l}$ with porcine cell monolayers, for 24 hours in an incubator.

\section{Experiment 5: Influence of porcine oviduct cells on equine IVF of in vivo matured oocytes}

After the recovery of in vivo matured oocytes, some COCs were mechanically denuded in the washing medium and some were kept intact. In the first trial, intact COCs were rinsed once in culture medium and co-incubated individually with or without porcine vesicles. In the second trial, intact COCs and denuded oocytes were rinsed once in culture medium and co-incubated individually with or without porcine cell monolayers.

COCs or denuded oocytes were co-incubated with or without porcine oviduct cells for 2 to 3 hours in an incubator. Spermatozoa (final concentration of $2.5 \times 10^{6}$ cells $\mathrm{ml}^{-1}$ ) from stallion A or stallion B were added with denuded oocytes or COCs. Gametes were co-incubated in a final volume of $50 \mu \mathrm{l}$ in the first trial or $515 \mu \mathrm{l}$ in the second trial, for 24 hours in an incubator.

During follicular punctures, immature equine COCs were also collected from small follicles as previously described [53] to compare in vivo and in vitro matured oocytes. Immature COCs were cultured in the maturation medium for 26 to 30 hours as described in "General methods" section. After in vitro maturation, all equine COCs were denuded, rinsed and co-incubated for 2 to 3 hours with cell monolayers in an incubator. Spermatozoa (final concentration of $2.5 \times 10^{6} \mathrm{cells} \mathrm{ml}^{-1}$ ) from stallion A or stallion $\mathrm{B}$ were added with denuded in vitro matured oocytes. Gametes were co-incubated in a final volume of $515 \mu \mathrm{l}$ with or without monolayer cells for 24 hours in an incubator.

\section{Experiment 6: Identification of oviductin, osteopontin and ANP A genes and proteins in equine species Identification of genes in the equine genome}

In NCBI and Ensembl databases (http:// www.ncbi.nlm.nih.gov/projects/genome/guide/horse/, http://www.ensembl.org/Equus caballus/Info/Index, [54]), we searched for the presence of OVGP1 gene encoding oviductin, SPP1 gene encoding osteopontin and NPPA gene encoding ANP A in the equine genome.

To check the truthfulness of database annotation, we computed tblastn [55] between amino acid sequence of bovine oviductin [RefSeq: NP_001073685], osteopontin [RefSeq: NP_776612] or ANP A [RefSeq: NP_776549] versus equin genome. Tblastn takes a protein query sequence and compares it against a nucleotide database which has been translated in all six reading frames. This program is useful to reveal the presence of stop codon and/or insertion/deletion in the nucleotide sequences. To focus on comparing DNA sequences at the level of its conceptual translation, regardless of sequencing error and introns, we used genewise [56]. Genewise compares a protein 
sequence to a genomic DNA sequence, allowing for introns and frameshifting errors.

The evolutionary distances between equine oviductin, osteopontin and ANP A and orthologue proteins from pig, human, mouse or cow were computed by MEGA4 $[57,58]$. This program uses protein sequences to compute an evolutionary distance matrix between every pair of sequences in a multiple sequence alignment, under four different models of amino acid replacement. Analyses were conducted using the Jones-Taylor-Thornton matrixbased method in MEGA4 model. The Jones-Taylor-Thornton model is similar to the Dayhoff PAM model, except that it is based on a recounting of the number of observed changes in amino acids and it uses a much larger sample of protein sequences than did Dayhoff. The distance is scaled in units of the expected fraction of amino acids changed (100 PAM's). Because its sample is so much larger this model is to be preferred over the original Dayhoff PAM model.

\section{Identification of proteins in the equine oviduct fluid using surface plasmon resonance}

In order to analyze whether osteopontin and ANP A are expressed in the equine oviduct, we used a surface plasmon resonance biosensor.

Equine oviducts were collected from slaughtered mares of unknown oestrus cycle stage in commercial slaughterhouses. Both oviducts were obtained immediately after mare were killed and transported dry to the laboratory within 2 hours. Oviducts were dissected free from surrounding tissues. The oviduct fluid and epithelial cells were expelled by gentle squeezing using a sterile microscope slide on a Petri dish and stored at $-20^{\circ} \mathrm{C}$. Before use, samples were centrifuged twice at $15000 \times \mathrm{g}$ for $15 \mathrm{~min}$ utes at $4^{\circ} \mathrm{C}$.

Surface plasmon resonance experiments were performed on BIAcore T100 (GE Healthcare). The antibodies (antihuman osteopontin, R\&D systems, Lille, France, and antihuman ANP A) were immobilized on a CM5 sensor chip (GE Healthcare), using standard amine coupling according to the manufacturer's instructions. Anti-human osteopontin antibody and anti-human ANP A antibody were immobilized at, respectively, 10500 resonance units (RU) and 14000 RU. BSA and rabbit serum immunoglobulins were used for reference surfaces and were immobilized at similar levels. Binding analyses were carried out at $25^{\circ} \mathrm{C}$ and a flow rate of $30 \mu \mathrm{l} \mathrm{min}^{-1}$. The centrifuged oviduct fluids were diluted in the running buffer $\left(10 \mathrm{mmol} \mathrm{l}^{-1}\right.$ Hepes, $150 \mathrm{mmol} \mathrm{l}^{-1} \mathrm{NaCl}, 0.05 \%$ (v/v) Tween 20 supplemented with $1 \mathrm{~g} \mathrm{l}^{-1} \mathrm{BSA}$ ). They were injected for 120 seconds. Dissociation was studied during 120 seconds. Regeneration of the surfaces was performed with $100 \mathrm{mmol} \mathrm{l}^{-1} \mathrm{H}_{3} \mathrm{PO}_{4}$ for 30 seconds.
Expression of osteopontin and ANP A during the oestrus cycle in the equine oviduct fluid

In order to analyze the expression of osteopontin and ANP A during the oestrus cycle, equine oviducts were collected from slaughtered cyclic Welsh pony mares from our experimental stud. Ovarian activity was assessed and induction of ovulation was performed as described in "General methods" section. Mares were slaughtered either when the largest follicle reached 22 to $25 \mathrm{~mm}$ (emergence of the dominant follicle, stage 1), when the largest follicle reached 35 to $36 \mathrm{~mm}$ (end of the follicular growth, stage 2 ), or 34 hours after induction of ovulation, just before ovulation (preovulatory stage, stage 3 ). Oviducts ipsilateral were obtained immediately after mare were killed and transported dry to the laboratory within a few minutes.

Oviducts were dissected free from surrounding tissues. The oviduct fluid and epithelial cells were expelled, stored and centrifuged as described above. The protein concentration was evaluated in each sample using the Coomassie prot assay reagent (Pierce, Thermo Fisher Scientific, Brebières, France). Samples were diluted in electrophoresis Laemmli buffer $\left(0.062 \mathrm{~mol} \mathrm{l}^{-1}\right.$ Tris-HCl pH 6.8, 5\% (v/ v) glycerol, $1 \%(\mathrm{w} / \mathrm{v})$ sodium dodecylsulfate, $0.5 \%(\mathrm{w} / \mathrm{v})$ blue-bromophenol, 2\% (v/v) 2-betamercaptoethanol at final concentration) and boiled at $95^{\circ} \mathrm{C}$ for 3 minutes.

Proteins were separated using $12 \%$ sodium dodecylsulfate polyacrylamide gel electrophoresis (SDS-PAGE). Acrylamide - bisacrylamide solution was purchased from Serva Electrophoresis GmbH (Heidelberg, Germany). For each sample, $50 \mu \mathrm{g}$ of total proteins were loaded on the gel. The proteins were then transferred onto a polyvinylidene difluoride membrane (hybond-P PVDF membrane transfert; Amersham Pharmacia Biotech, Orsay, France) for 2 hours.

The membrane was washed with TBS $\left(1.21 \mathrm{~g} \mathrm{l}^{-1}\right.$ Tris Base, $\left.9 \mathrm{~g} \mathrm{l}^{-1} \mathrm{NaCl}, \mathrm{pH} 7.4\right)$ containing $0.1 \%(\mathrm{v} / \mathrm{v})$ Tween-20 (TBS-T), incubated overnight in blocking solution $(5 \%$ (w/v) non-fat dry milk, $0.2 \%(\mathrm{v} / \mathrm{v})$ IGEPAL $^{\circledast}, \mathrm{pH} 7.4$ in TBS), and incubated for 3 hours with the primary antibodies (anti-human osteopontin or anti-human ANP A) diluted 1/500 in TBS-T. The membrane was washed with TBS-T, incubated for 1 hour in blocking solution, incubated for 1 hour with peroxidase-conjugated secondary antibodies (mouse anti-goat IgG, Jackson ImmunoResearch Laboratories, Newmarket, United Kingdom) diluted 1/2000 in blocking solution and washed with TBS-T. The peroxydase activity was revealed using the ECL-Plus Western blotting detection system (Amersham Pharmacia Biotech). Two blots were performed for each condition.

Checking for a potential expression of oviductin in the equine oviduct To check the hypothesis that OVGP1 has become a pseudogene in horse genome, and consequently that oviductin 
is not translated, we checked the presence of oviductin in the equine oviduct. For this purpose, equine oviduct fluid and cells were prepared as previously described and proteins were submitted to the Western blot technique described above, except that the primary antibody was anti-bovine OGP (kindly donated by P.A. Mavrogianis at University of Illinois in USA [59]) and the secondary antibody was goat anti-rabbit IgG (Eurobio, Courtaboeuf, France).

\section{Experiment 7: Influence of osteopontin and ANP A on equine IVF}

After in vitro maturation, all equine COCs were denuded and washed. Oocytes (10 to 20 per group) were co-incubated with or without purified osteopontin from bovine milk or synthesized human ANP A for 2 to 3 hours in a final volume of $45 \mu \mathrm{l}$ of culture medium covered with 500 $\mu \mathrm{l}$ of mineral oil in an incubator. Five trials were performed: 1) osteopontin at final concentration of $0,0.01$ or $\left.1 \mu \mathrm{g} \mathrm{ml}^{-1}[17], 2\right)$ osteopontin at final concentration of 0 , 0.1 or $\left.10 \mu \mathrm{g} \mathrm{ml}^{-1}[17,19], 3\right)$ osteopontin at final concentration of 0,50 or $\left.100 \mu \mathrm{g} \mathrm{ml}^{-1}[18], 4\right)$ ANP A at final concentration of 0,1 or $\left.10 \mathrm{nmol} \mathrm{l}^{-1}[22], 5\right)$ ANP A at final concentration of $0,0.1$ or $50 \mathrm{nmol} \mathrm{l}^{-1}$. Each trial was repeated twice (once with stallion $A$ and once with stallion B).

Spermatozoa (final concentration of $2.5 \times 10^{6}$ cells $\mathrm{ml}^{-1}$ ) from stallion A or stallion B were added with oocytes.

B

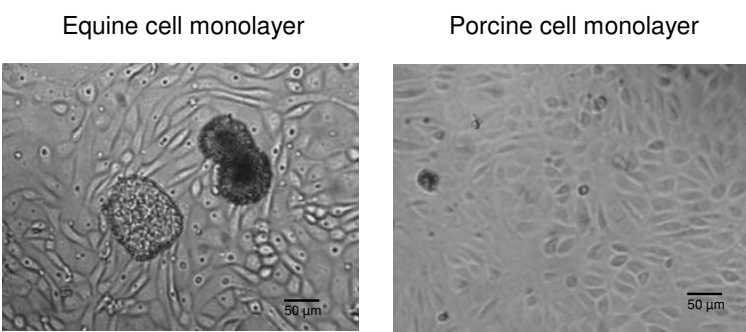

D

IVF rates

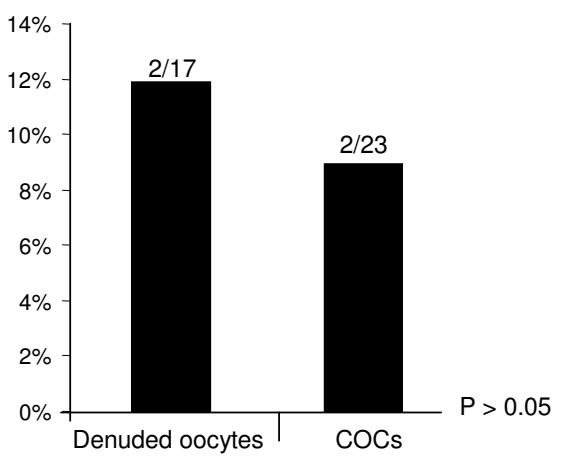

\section{Figure I}

Influence of oviduct cells and/or cumulus cells on equine IVF. A) In vitro fertilization rates (IVF, percentage of fertilized oocytes per matured oocytes) of equine gametes co-incubated with or without porcine vesicles; the IVF rates in the two groups are significantly different (*: $\mathrm{P} \leq 0.05)$; B) Equine and porcine cell monolayers observed by microscopy at magnification $\times 400$. C) IVF rates of equine gametes co-incubated with equine or porcine vesicles or cell monolayers; the IVF rates in the four groups are not significantly different (P > 0.05); D) IVF rates of denuded oocytes or cumulus-oocyte complexes (COCs) in the presence of porcine vesicles; the IVF rates in the two groups are not significantly different $(P>0.05)$. The fractions represent the number of fertilized oocytes out of matured oocytes (oocytes in metaphase II, activated and fertilized). 
Gametes were co-incubated for 24 hours in a final volume of $50 \mu \mathrm{l}$ in an incubator.

\section{Results}

In each experiment, no significant difference in in vitro fertilization (IVF) rates was observed between stallion A and stallion B.

\section{Experiment I: Influence of porcine vesicles and cell monolayers on equine IVF}

In the first trial, the co-incubation of equine gametes with porcine vesicles significantly increased the IVF rates compared to the co-incubation of equine gametes without vesicles ( $9 \%$ vs $0 \%$ respectively, $\mathrm{P} \leq 0.05$; Figure $1 \mathrm{~A}$ ). In the second trial, equine oocytes incubated with $(n=21)$ or without $(n=27)$ porcine cell monolayers were not fertilized.

\section{Experiment 2: Influence of equine vs porcine vesicles and} cell monolayers on equine IVF

Figure 1B shows the cell monolayers from equine or porcine oviduct epithelial cells after 7 days of culture. The equine IVF rates were not significantly different between gametes co-culture with equine and porcine vesicles or cell monolayers ( $\mathrm{P}>0.05$; Figure $1 \mathrm{C})$.

\section{Experiment 3: Influence of equine cumulus cells on equine IVF}

In experiment 3, equine gametes were co-incubated with porcine vesicles. The IVF rates were not significantly different between equine COCs and denuded oocytes $(P>0.05$; Figure 1D).

\section{Experiment 4: Influence of hormonal stimulation of porcine oviduct cells on equine IVF}

In experiment 4, equine gametes were co-incubated with oviduct epithelial cells (vesicles or cell monolayers) stimulated or not with $\mathrm{LH}, \mathrm{hCG}$ or $\mathrm{E}_{2}$. The equine IVF rates were not significantly different between stimulated and not stimulated oviduct cells ( $\mathrm{P}>0.05$; Figure 2). Moreover, when gametes were co-incubated with oviduct cells co-stimulated with $\mathrm{LH}$ and $\mathrm{E}_{2}$, the equine IVF rate was slightly higher than with non stimulated oviduct cells, but the difference is not significant $(\mathrm{P}>0.05$; Figure 2).

\section{Experiment 5: Influence of porcine oviduct cells on equine IVF of in vivo matured oocytes}

In the first trial, 6 and 4 in vivo matured intact COCs were co-incubated with or without porcine vesicles respectively. No fertilization was observed after gametes coincubation with or without vesicles.

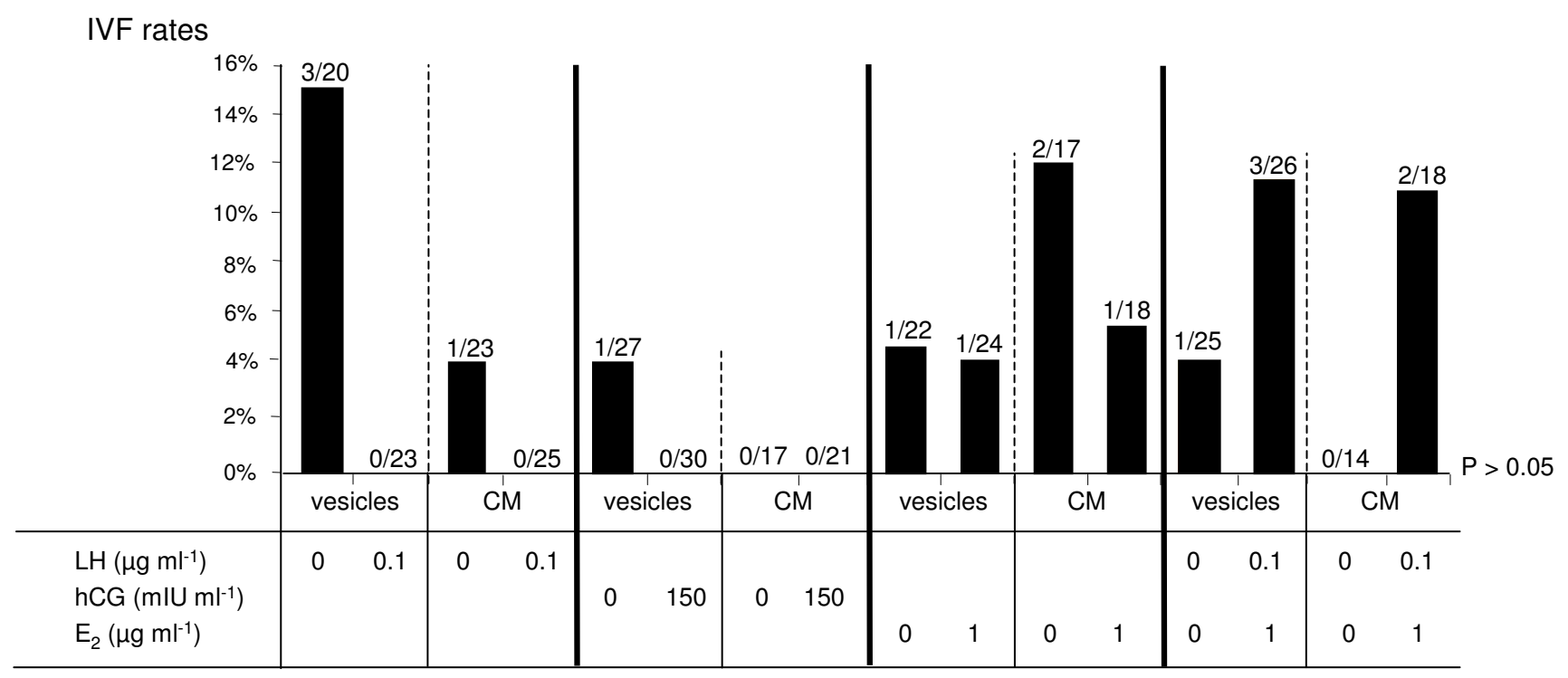

\section{Figure 2}

Influence of hormonal stimulation of oviduct cells on equine IVF. In vitro fertilization rates (IVF, percentage of fertilized oocytes per matured oocytes) of equine gametes co-incubated with vesicles or cell monolayers (CM) previously stimulated or not with porcine Luteinizing Hormone (LH), human Chorionic Gonadotropin (hCG), Estradiol- 17 beta $\left(E_{2}\right)$ or $L H+$ $E_{2}$. No significant statistical difference was observed $(P>0.05)$. The fractions represent the number of fertilized oocytes out of matured oocytes (oocytes in metaphase II, activated and fertilized). 
In the second trial, 5 in vivo matured intact COCs and 5 in vivo matured denuded oocytes were co-incubated with cell monolayers and 5 in vivo matured intact COCs without cell monolayers. No fertilization of COCs or denuded oocytes was observed after gametes co-incubation with or without cell monolayers.

At the same time, $6 \%$ of equine in vitro matured oocytes $(n=15)$ were fertilized after their co-incubation with cell monolayers. No significant difference was observed between in vivo and in vitro matured oocytes $(\mathrm{P}>0.05)$.

Experiment 6: Identification of oviductin, osteopontin and ANP A genes and proteins in equine species

Identification of genes in the equine genome

SPP1 gene encoding osteopontin was found in horse genome as [RefSeq: XP_001496202]. The gene is known by projection protein coding, but there are a lot of crossed supporting evidences to show the veracity of this gene. Moreover exons/introns prediction seems probable.

NPPA gene encoding ANP A was found in horse genome as [Ensembl: ENSECAG00000014892]. The protein coding is known and a crossed supporting evidences of reality of this gene is an alignment with [EMBL: X58563] horse mRNA.

OVGP1 gene encoding oviductin was found in horse genome as [Ensembl: ENSECAT00000024758]. The gene is known by projection protein coding, and there are so few crossed supporting evidences to validate the veracity of this gene. Moreover exons/introns prediction seems not probable because some introns of one base pair were detected. No EST was found for this gene in horse Unigene http://www.ncbi.nlm.nih.gov/UniGene/

UGOrg.cgi?TAXID=9796. The result of tblastn of cow oviductin $v s$ horse genome is a match located on horse chromosome 5 between WDR77 and C3H1orf88 genes. The alignment shows the presence of stop codons. To understand which event appears to create these stop codons, we used genewise. Figure 3 shows the alignment of cow oviductin protein sequence $v$ s the large corresponding horse genomic sequence with a corrupted exon by a stop codon. This stop codon is due to the absence on horse genomic sequence of 5 nucleic base pairs in comparing with cow genomic sequence (Figure 4). This absence induces a frameshift and the coding of stop codon TAA. Thus, we could suppose that horse OVGP1 gene might be either a pseudogene or the result of sequencing error.

Evolutionary distance computation between horse proteins predicted in databases (osteopontin, ANP A and oviductin) and respective orthologue proteins of cow, pig, human and mouse is given in table 1 . Evolutionary dis- tance computing shows that horse and cow or human target proteins are not so far between them.

\section{Identification of proteins in the equine oviduct fluid using surface plasmon resonance}

We analyzed the presence of osteopontin and ANP A in oviducts collected from mares of unknown oestrus cycle stage using a surface plasmon resonance biosensor.

Surface plasmon resonance experiments showed that the injection of a diluted oviduct fluid resulted in a binding to the anti-osteopontin antibody surface (Figure 5A) and to the anti-ANP A antibody surface (Figure 5B). These results show that osteopontin and ANP A are present in the equine oviduct fluid.

Expression of osteopontin and ANP A during the oestrus cycle in the equine oviduct fluid

We analyzed the expression of osteopontin and ANP A using gel electrophoresis and immunoblotting in oviducts collected from mares slaughtered 1) at the time of emergence of the dominant follicle, 2) at the end of the follicular growth, 3) at the preovulatory stage.

The antibody raised against osteopontin revealed a band between 50 and $60 \mathrm{kDa}$ in equine oviducts in the three stages of the estrus cycle (Figure 5C). Moreover, the antibody raised against ANP A revealed a band between 15 and $20 \mathrm{kDa}$ in equine oviducts in the three stages of the estrus cycle (Figure 5D). Thus, the gel electrophoresis and immunoblotting technique confirmed the expression of osteopontin and ANP A in the equine oviduct. No obvious difference of the amount of osteopontin or ANP A was observed between the three stages.

Checking for a potential expression of oviductin in the equine oviduct The antibody raised against bovine oviductin did not reveal any signal in equine oviducts (data not shown). This could be due to the absence of oviductin or to the lack of cross-reactivity between the antibody and the equine oviductin. We previously checked that this antibody revealed a band at $97 \mathrm{kDa}$ in the bovine oviduct.

\section{Experiment 7: Influence of osteopontin and ANP A on equine IVF}

After co-incubation of equine oocytes with or without purified osteopontin, the IVF rates were not significantly different between $0,0.01$ and $1 \mu \mathrm{g} \mathrm{ml}^{-1}$, between $0,0.1$ and $10 \mu \mathrm{g} \mathrm{ml}^{-1}$, or between 0,50 and $100 \mu \mathrm{g} \mathrm{ml}^{-1}$ of osteopontin ( $\mathrm{P}>0.05$; Figure $6 \mathrm{~A})$, albeit a slight increase with $10 \mu \mathrm{g} \mathrm{ml}-1$ of osteopontin. Moreover, when the oocytes were co-incubated with high doses of osteopontin (50 and $100 \mu \mathrm{g} \mathrm{ml}^{-1}$ ), lots of them degenerated, and thus were not taken into account. 

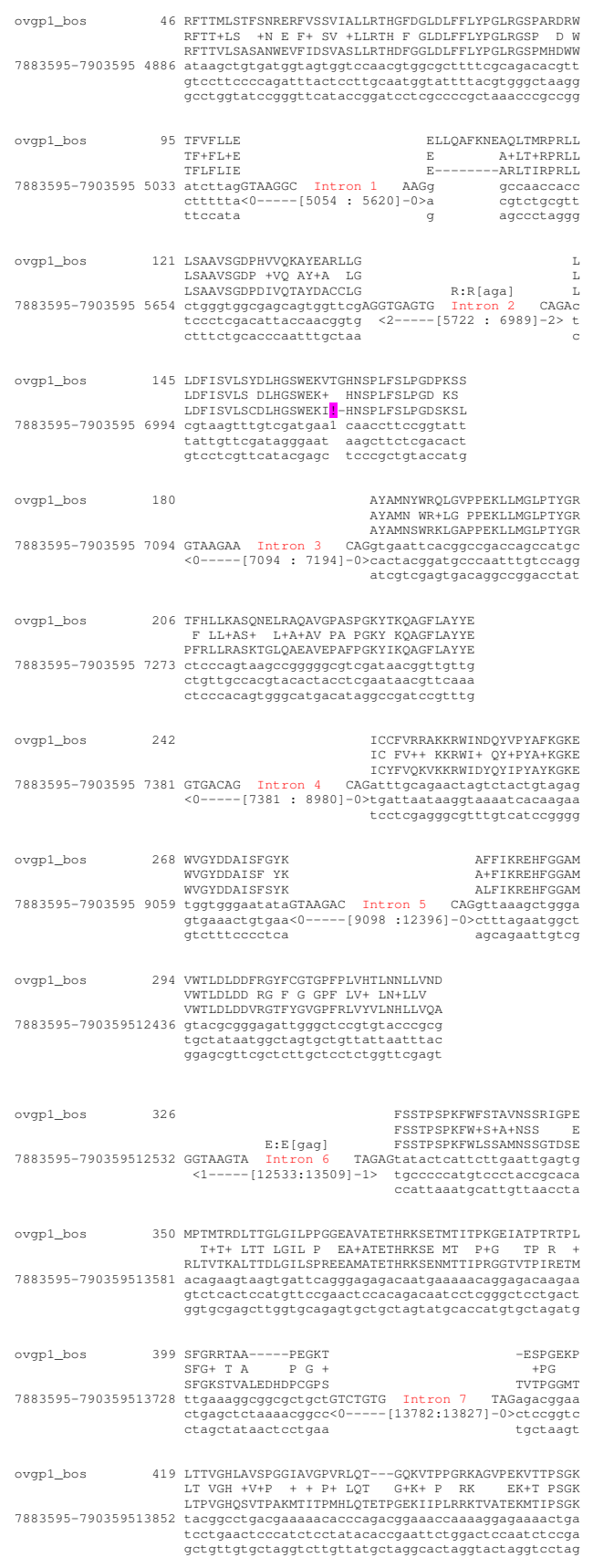

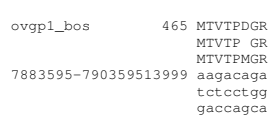

\section{Figure 3}

Alignment of cow oviductin with horse chromosome 5 DNA sequence. The alignment shows the cow OVGPI protein sequence on the first line. The second line indicates the similarity level of the match. The following 4 lines represent the DNA sequence of the part of horse chromosome 5 (location between 7883595-7903595 bp, strand +) where OVGPI gene is predicted and its translation. The DNA sequence is presented with the exons descending in triplets, each triplet being a codon. The translation of each codon is shown above it. In introns the DNA sequence is not shown but for the first 7 bases making the $5^{\prime}$ splice site and the last 3 bases of the 3 ' splice site. The intervening sequence is indicated in the square brackets. The pink exclamation point represents a sequence disruption. 


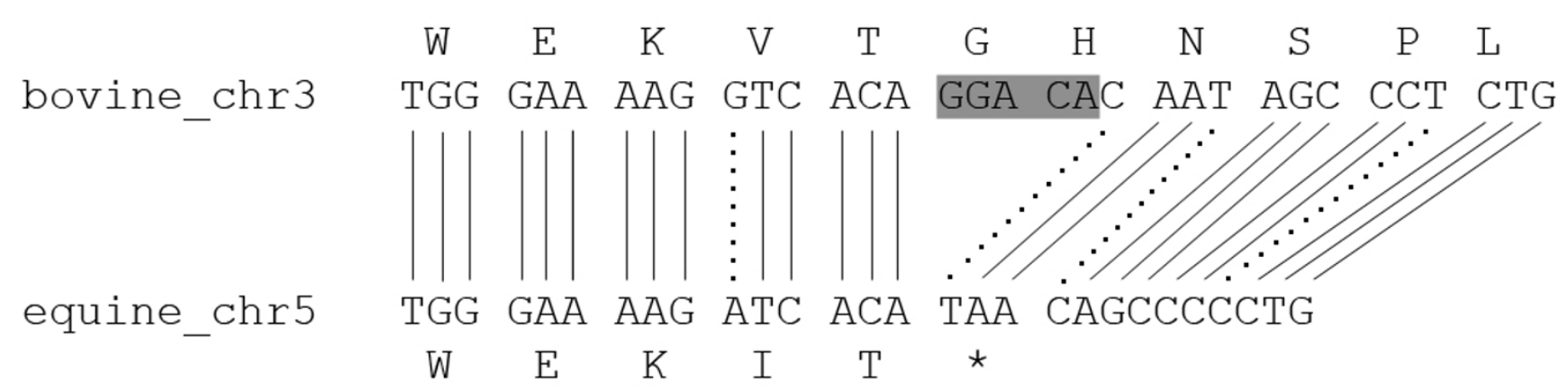

Figure 4

Alignment of cow OVGP I DNA region and horse chromosome 5 DNA sequence. Extract of result of blastn between OVGPI DNA regions on chromosome 3 and chromosome 5 respectively from cow and horse. Star represents stop codon provoked by absence on horse genome of five nucleic bases highlighted in grey on cow genome. Dashed lines correspond to mismatches.

After co-incubation of equine oocytes with or without synthesized ANP A, the IVF rates were not significantly different between 0,1 and $10 \mathrm{nmol} \mathrm{l}^{-1}$ of ANP A, or between $0,0.1$ and $50 \mathrm{nmol} \mathrm{l}^{-1}$ of ANP A $(\mathrm{P}>0.05$; Figure 6B).

\section{Discussion}

In mammals, the oviduct epithelial cells and oviduct secretory products facilitate gametes transport and maturation, fertilization and early embryo development [1]. Our first objective was to verify the beneficial effect of the oviduct cells and fluid on the equine in vitro fertilization (IVF). Our results show that the co-culture of oviduct epithelial cells with equine gametes increased the IVF rate.

In our conditions, the IVF rate was higher for equine gametes co-incubated with porcine vesicles than without oviduct cells. In addition, after co-incubation of equine gametes with oviduct cells, the IVF rate was not different between porcine and equine oviduct cells. The beneficial effect of homologous oviduct cells on in vitro production of embryos is also demonstrated in human $[5,6]$, bovine $[7-9]$, porcine $[10,11]$, deer $[12,13]$ and dromedary $[14]$

Table I: Evolutionary distances between horse proteins predicted in databases and orthologue proteins of cow, pig, human and mouse

\begin{tabular}{lllll}
\hline & Cow & Pig & Human & Mouse \\
\hline osteopontin_horse & 0.391 & 0.332 & 0.283 & 0.451 \\
ANP-A_horse & 0.154 & 0.138 & 0.154 & 0.233 \\
oviductin_horse & 0.403 & 0.388 & 0.337 & 0.516 \\
\hline
\end{tabular}

The number of amino acid substitutions per site from analysis between sequences is shown between osteopontin, ANP A and oviductin horse proteins and their orthologues of cow, pig, human and mouse. All results per protein are based on the pairwise analysis of 5 sequences. Analyses were conducted using the JTT matrix-based method in MEGA4. All positions containing gaps and missing data were eliminated from the dataset. species. Several studies show a positive effect of heterologous oviduct cells on gametes, fertilization and embryo development. For example, the development of deer embryos is improved in sheep oviduct [12] or with ovine oviduct epithelial cells in culture [13]. Isolated mouse oviduct is capable of supporting development of bovine embryos [60]. Similar numbers of canine or human spermatozoa bind to heterologous or homologous oviducts and the capacitating responses are not different between homologous and heterologous oviducts $[61,62]$. In our study, we collected equine and porcine oviducts from 4 to 6 hours after ovulation. In vivo, fertilization has been shown to occur during this period in equine or porcine species $[63,64]$. Moreover, porcine oviduct cells have a better competence to support porcine embryo development when they are collected at ovulation or corpus luteum stages than at other ovarian cyclic stages [65]. Thus, we used oviduct cells collected during the in vivo fertilization period to keep the favourable environment of fertilization.

In our study, equine oocytes were co-incubated with oviduct cells for 2 to 3 hours before IVF. Indeed, equine IVF rates increase when oocytes are collected from the oviduct compared to preovulatory oocytes $[24,63]$ or when preovulatory oocytes are pre-incubated in the fertilization medium before gametes co-incubation [24]. In bovine and porcine species, the co-culture of oocytes with oviduct cells before gametes co-incubation, improves the IVF rates $[15]$ and promotes the association of oviductal proteins with the zona pellucida [66-68]. In addition, during the co-culture of porcine oocytes with porcine oviduct cells, the structure of the zona pellucida is modified [[69] for review] and the cortical granules migrates near the cortex $[70,71]$. The co-incubation of oocytes with oviduct cells may have a positive effect on their competence for fertilization. Further studies would be necessary to clarify the 

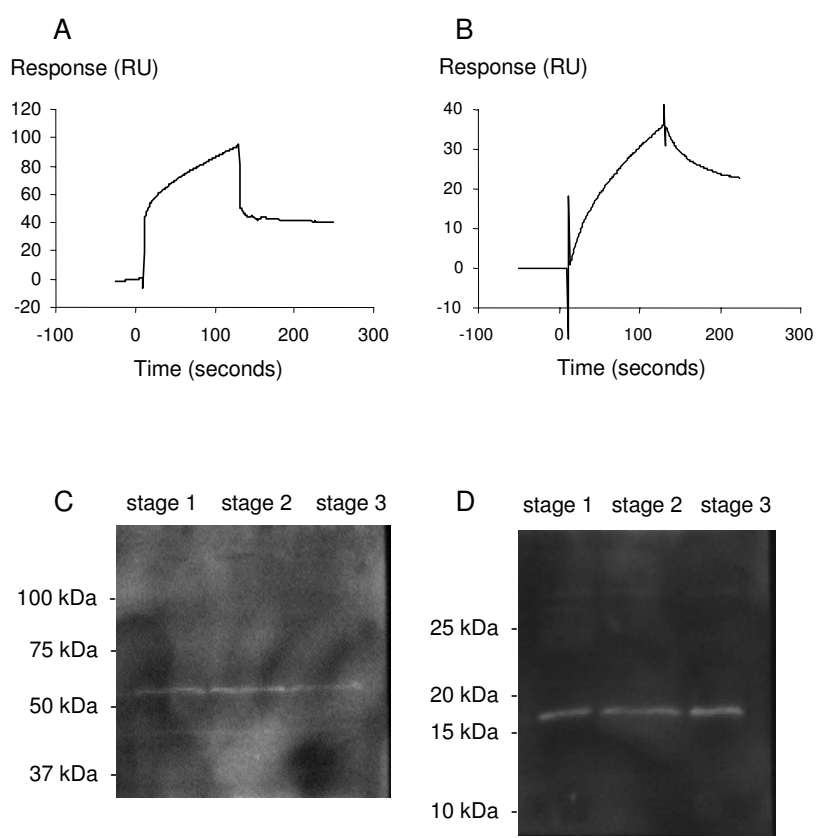

\section{Figure 5}

Surface plasmon resonance binding and Western blot data. Surface plasmon resonance binding data $(A, B)$ : oviduct fluid diluted $\mathrm{I} / 25$ was injected on anti-osteopontin antibody (A) or anti- ANP A antibody (B) surface. The sensorgramms show an association phase (increasing response) during the 120 seconds injection of fluid, followed by a dissociation phase (decreasing response) studied for 120 seconds. Shown sensorgramms have been subtracted from the sensorgramms obtained on their reference surface. Western blot data (C, D): Osteopontin (C) and ANP A (D) protein expression in equine oviducts from stage I (emergence of the dominant follicle, lane I), stage 2 (end of the follicular growth, lane 2) and stage 3 (preovulatory stage, lane 3).

interaction between equine oocytes and oviduct secretions.

In our conditions, the equine IVF rate with oviduct cells was low. We hypothesized that most of the equine in vitro matured oocytes may not be competent for fertilization. However, equine in vitro matured oocytes can undergo in vivo fertilization after intraoviductal transfer like in vivo matured oocytes [45,46]. Moreover, we analyzed the influence of oviduct cells on the IVF of in vivo matured oocytes. Our results showed that the presence of oviduct cells did not improve the IVF of equine in vivo matured oocytes. After co-incubation with oviduct cells, the IVF rate was not different between in vivo and in vitro matured oocytes. Thus, our low IVF rate may not be due to a low competence of in vitro matured oocytes.

Then, we hypothesized that the removal of cumulus cells had decreased the IVF rates. Indeed, in the pig, the absence of cumulus cells significantly decreases the IVF rates with or without oviduct cells [72-74]. In cattle, the absence of cumulus cells decreases the number of blastocysts in presence or absence of oviduct cells $[75,76]$. In equine species, most IVF techniques use oocytes without cumulus cells [25-27], but to our knowledge, no comparison of denuded and intact oocytes have been published. Our results showed that, in our conditions, the equine IVF rate was not different between oocytes with or without cumulus cells. Thus, the absence of cumulus cells doesn't appear to be responsible for our low in vitro fertilization rate. In equine species, the cumulus cells could not be essential for in vitro fertilization unlike in porcine or bovine species. However, further studies would be necessary to clarify this point.

We further postulated that the secretions from oviduct cells in culture were not optimal in our conditions. In porcine species, the oviductal secretory proteins are under oestrogen and LH control $[23,77]$. Thus, we co-incubated equine gametes with porcine oviduct cells previously stimulated with $1 \mu \mathrm{g} \mathrm{ml}^{-1}$ of $\mathrm{E}_{2}, 0.1 \mu \mathrm{g} \mathrm{ml}^{-1}$ of porcine $\mathrm{LH}$, $150 \mathrm{mIU} \mathrm{ml}^{-1}$ of hCG or LH and $\mathrm{E}_{2}$. Our results showed that the hormonal stimulation of porcine oviduct cells had no beneficial effect on equine IVF.

The co-culture of porcine gametes with oviduct cells previously stimulated for 48 hours with $1 \mu \mathrm{g} \mathrm{ml}^{-1}$ of $\mathrm{E}_{2}$ significantly increase the cleavage rate [78]. Although we used the same dose of $\mathrm{E}_{2}$, the hormonal stimulation may have been too short ( 24 hours) in our conditions. It has been reported that the stimulation of bovine oviduct cells with $150 \mathrm{mIU} \mathrm{ml}^{-1}$ of hCG increase the oviductal glycoprotein secretion [79] and the percentage of bovine blastocyst [80]. Our results suggest that hCG may be inefficient on porcine oviduct cells, but further studies are necessary to clarify this point. In porcine species, $100 \mathrm{ng} \mathrm{ml}^{-1}$ of LH has been shown to be efficient to induce relaxation of the oviduct [81], but, in our conditions, it could be inefficient for stimulation of porcine oviduct secretions.

Then, we postulated that the co-stimulation of $\mathrm{E}_{2}$ and $\mathrm{LH}$ could increase the porcine oviductal secretion. In porcine species, $\mathrm{E}_{2}$ increases the quantity of $\mathrm{LH}$ receptors in ciliated cells [82]. However, in our conditions, this co-stimulation did not have any effect on the IVF rate, and thus probably on the secretions of porcine oviduct cells in culture. In this study, due to the low number of equine oocytes available, only one concentration was tested for each hormone, according to the efficient concentrations published in the literature. This concentration could not be the efficient one to stimulate porcine oviductal secretions. Different combinations of hormone concentrations should ideally be investigated to evaluate the effect of $\mathrm{E}_{2}$, LH and hCG on porcine oviduct secretions. 


\section{A}

\section{IVF rates}

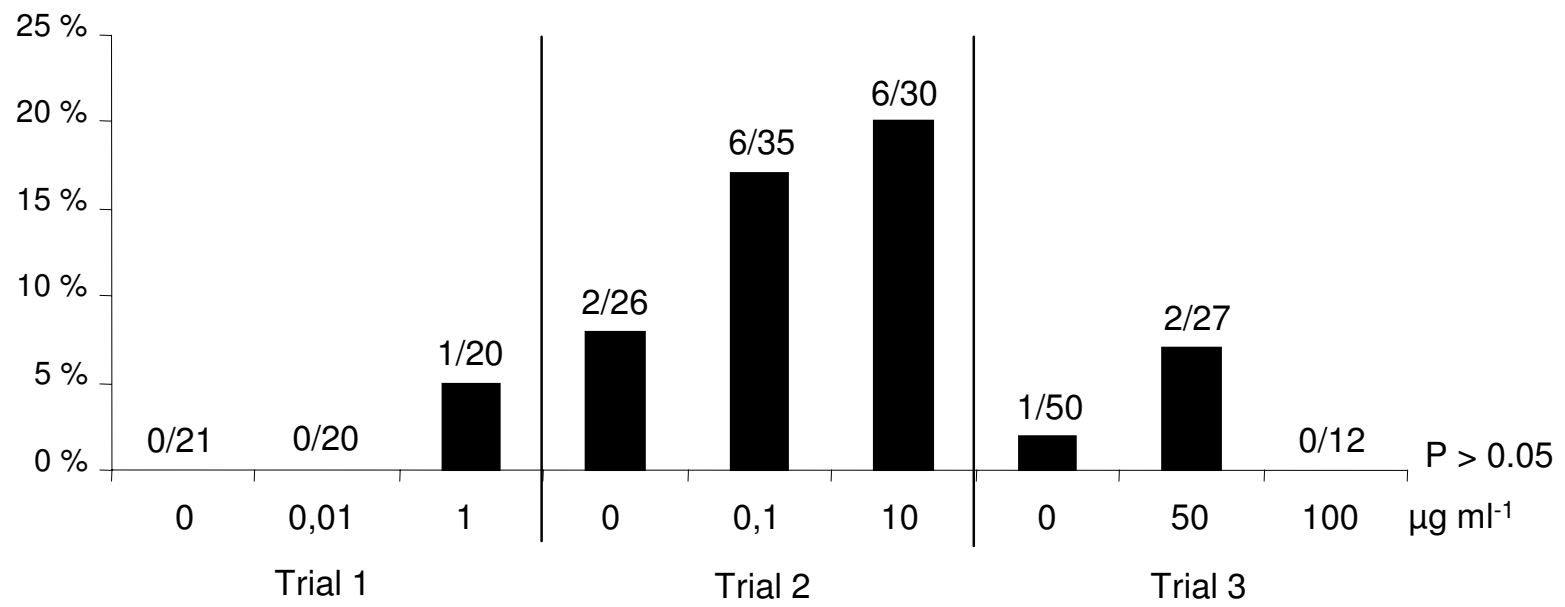

B

\section{IVF rates}

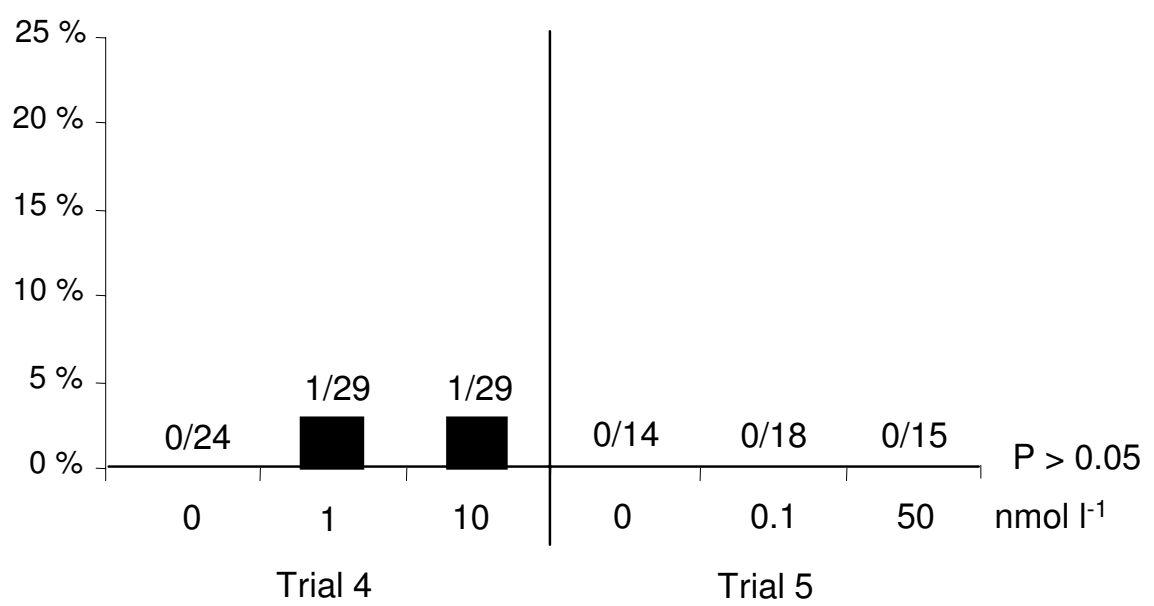

Figure 6

Influence of osteopontin and ANP A on equine IVF. In vitro fertilization rates (IVF, percentage of fertilized oocytes per matured oocytes) of equine gametes. A) Gametes co-incubated with or without bovine osteopontin; in each trial, the IVF rates were not significantly different between the three concentrations $(P>0.05)$; B) Gametes co-incubated with or without bovine ANP A; in each trial, the IVF rates were not significantly different between the three concentrations $(P>0.05)$; The fractions represent the number of fertilized oocytes out of matured oocytes (oocytes in metaphase II, activated and fertilized).

Finally, the limited number of equine oocytes available for studies did not allow us to test different sperm preparations. We used fresh equine semen treated with calcium ionophore A23187 because this treatment previously allowed equine IVF [24] in a repeatable way $[83,26,45]$. However, other sperm preparations should be tested, that use fresh or frozen semen treated with calcium ionophore or heparin $[25,26]$. Recently, a new IVF technique based on sperm hyperactivation has been published [27] but unfortunately, up to now, we are not able to obtain high IVF rates with this technique. The potential reasons for the low IVF rate in the horse are difficult to identify, due to the rather low number of conditions that have been tested, and the low number of oocytes used in each experiment. 
Our second aim was to identify the proteins from the oviduct involved in fertilization in the horse. Our study suggests that the molecules secreted by equine or porcine oviduct cells have a positive effect on the equine IVF rate. In porcine, bovine and human species, osteopontin, oviductin and ANP A, which are secreted in oviduct fluid, increase the IVF rates and improve the early embryo development $[9,10,17,21-23,84,85]$. We postulated that these molecules could have a positive effect on the equine IVF.

In our study, we showed that OVGP1 gene encoding oviductin has a stop codon in equine genome. Moreover, we were not able to show the expression of oviductin in equine oviduct by Western blot. This could be due either to the absence of oviductin or to the lack of cross-reactivity between the antibody and the equine oviductin despite a weak evolutionary distance between equine and bovine oviductin. Subsequently, on the one hand, we might suppose that OVGP1 is a pseudogene, i.e. a gene that has accumulated mutations during time and is become inactive, as previously described in the rat [86]. On the other hand, this stop codon is maybe due to sequencing error, engendering a frameshift. In the case where we suppose that OVGP1 is a pseudogene, we might suppose that, conversely to what has been described in human, bovine and porcine species $[9,10,23]$, oviductin may not be involved in the mechanism of fertilization in the equine. However, oviductin belongs to the mammalian family of chitinaselike proteins $[23,87]$. We could hypothesise that one or more other chitinases could be present in equine oviduct fluid and involved in equine fertilization. Further studies would be necessary to clarify this point.

We found the gene encoding osteopontin in equine genome and confirmed its expression in the equine oviduct fluid throughout follicle growth and maturation. Thus, equine oviduct cells secrete osteopontin like porcine, human and bovine oviduct cells $[17,84,85]$. Our results showed a slight increase of equine IVF rate with 10 $\mu \mathrm{g} \mathrm{ml}^{-1}$ bovine osteopontin although it was not significant. In bovine species, the co-incubation of spermatozoa and oocytes with $10 \mu \mathrm{g} \mathrm{ml}^{-1}$ bovine osteopontin before IVF increases the fertilization and cleavage rates $[18,19]$. In pigs, supplementation of the IVF medium with $0.1 \mu \mathrm{g}$ $\mathrm{ml}^{-1}$ rat osteopontin increases the cleavage rates and the percentage of blastocysts [17]. Although we tested a wide range of concentration of bovine osteopontin, no significant effect on equine IVF rates was observed. It could be suggested that despite a weak evolutionary distance between equine and bovine osteopontin, bovine osteopontin is too divergent and could not interact with equine gametes.

We found the gene encoding ANP A in equine genome and confirmed its expression in the equine oviduct fluid throughout follicle growth and maturation. In cattle, pig and human, ANP A is also present in the oviduct $[21,22,88]$. Despite a weak evolutionary distance between equine and human ANP A, the presence of human ANP A with equine gametes did not improve the IVF rates. Nevertheless, human ANP A can have an effect on heterologous cells since $1 \mathrm{nmol} \mathrm{l}^{-1}$ of human ANP A improve the IVF in porcine species [22]. In human, porcine and bovine species, 1 or $10 \mathrm{nmol} \mathrm{l}^{-1}$ of human or rat ANP A incubated with spermatozoa improve the acrosome reaction of spermatozoa $[21,22,89]$. We could hypothesize that human ANP A did not interact with equine gametes in our conditions, or that the concentration of ANP A was not efficient.

Due to the limited number of equine oocytes available for studies, few conditions were tested in our experiments. Further studies would be necessary to test osteopontin and ANP from other species, other concentrations, sperm preparations and IVF conditions.

Finally, the oviduct fluid contains many proteins and some of them have been identified in pig and cattle [9093]. The proteins that are involved in equine IVF may be different from osteopontin and ANP A, and several candidates have to be tested. Moreover, osteopontin and ANP A could be involved in fertilization through interactions with other oviductal proteins to facilitate sperm-oocyte interaction. Further experiments would be necessary to characterize the proteins from equine oviduct and study their role in equine IVF.

Our study showed that the surface plasmon resonance technique is a new and efficient method to detect molecules secreted by oviduct epithelial cells. This technology allows qualitative analysis of complex fluid, measurement of analyte concentration, and determination of affinity of molecular interaction in real time, without the need for a molecular tag or label $[94,95]$. It appears to be a sensitive and powerful tool to study the molecules and the molecular interactions involved in the mechanism of fertilization.

\section{Conclusion}

In conclusion, our study reports beneficial effects of equine or porcine oviduct epithelial cells co-culture on equine IVF rates even if these remain low. We showed that OVGP1 is maybe a pseudogene in equine genome, and that osteopontin and ANP A are expressed in the equine oviduct. The role of these molecules remains under question, and further studies are in process to clarify this point.

\section{Competing interests}

The authors declare that they have no competing interests.

\section{Authors' contributions}

SM, MK, SC, GP and GG participated in the design of the study. SM, SC, GP and GG wrote the manuscript. SM, MK, 
$\mathrm{CD}$ and GG performed the experiments 1 to 4 and 7. SM, $\mathrm{CD}, \mathrm{SD}, \mathrm{GD}$ and GG performed the experiment 5. SM, CD, SC, GP, PM and GG performed the experiment 6 . All authors read and approved the final manuscript.

\section{Acknowledgements}

We thank "Les Haras Nationaux" in France for financial support. Sylvie Mugnier is financially supported by "Les Haras Nationaux" and "Le Conseil Régional de la Région Centre" in France.

We would like to thank the staff of the experimental stud and pigsty at the "Unité Expérimentale de Physiologie Animale de l'Orfrasière", Jean-Philippe Dubois, Albert Arnould, Gaël Ramé, Thierry Delpuech at the "Unité de Physiologie de la Reproduction et des Comportements", and Stéphane Boittin and Carolina Rodriguez for their contribution to this work. We wish to thank J-F Beckers at University of Liege in Belgium for providing porcine LH and P.A. Mavrogianis at University of Illinois in USA for providing anti-OGP antibodies, Nadine Gérard for providing equine oviduct, Yann Locatelli, Pascal Mermillod, Nati Poulin, Michèle Magistrini, Barbara Schmaltz-Panneau and Marie-Christine Maurel for constructive discussions and technical help.

\section{References}

I. Yanagimachi R: Mammalian fertilization. In The Physiology of Reproduction Volume I. Edited by: Knobil E, Neill JD. New York: Raven Press; 1994:189-317.

2. Leese $\mathrm{HJ}$ : The formation and function of oviduct fluid. J Reprod Fertil 1988, 82:843-856.

3. Verhage HG, Mavrogianis PA, Boice ML, Li W, Fazleabas AT: Oviductal epithelium of the baboon: hormonal control and the immuno-gold localization of oviduct-specific glycoproteins. Am J Anat 1990, 187:81-90.

4. Abe H: The mammalian oviduct epithelium: regional variations in cytological and functional aspects of the oviductal secretory cells. Histol Histopathol 1996, II:743-768.

5. Bongso $\mathrm{A}, \mathrm{Ng} \mathrm{SC}$, Fong $\mathrm{CY}$, Ratnam S: Improved fertilization rates of human oocytes in coculture. J In Vitro Fert Embryo Transf |991, 8:216-22|.

6. Kervancioglu ME, Saridogan E, Atasü T, Camlibel T, Demircan A, Sarikamis B, Djahanbakhch O: Human Fallopian tube epithelial cell co-culture increases fertilization rates in male factor infertility but not in tubal or unexplained infertility. Hum Reprod 1997, I 2:1253-1258

7. Chian RC, Sirard MA: Fertilizing ability of bovine spermatozoa cocultured with oviduct epithelial cells. Biol Reprod 1995, 52:156-162.

8. Way AL, Schuler AM, Killian GJ: Influence of bovine ampullary and isthmic oviductal fluid on sperm-egg binding and fertilization in vitro. I Reprod Fertil 1997, 109:95-101.

9. Martus NS, Verhage HG, Mavrogianis PA, Thibodeaux JK: Enhancement of bovine oocyte fertilization in vitro with a bovine oviductal specific glycoprotein. / Reprod Fertil 1998, I | 3:323-329.

10. McCauley TC, Buhi WC, Wu GM, Mao J, Caamano JN, Didion BA, Day BN: Oviduct-Specific Glycoprotein modulates spermzona binding and improves efficiency of porcine fertilization in vitro. Biol Reprod 2003, 69:828-834.

II. Romar R, Coy P, Campos I, Gadea J, Matas C, Ruiz S: Effect of coculture of porcine sperm and oocytes with porcine oviductal epithelial cells on in vitro fertilization. Anim Reprod Sci 200I, 68:85-98.

12. Berg DK, Thompson JG, Pugh PA, Tervit HR, Asher GW: Successful in vitro culture of early cleavage stage embryos recovered from superovulatory red deer (Cervus elaphus). Theriogenology 1995, 44:247-254.

13. Locatelli $Y$, Cognié $Y$, Vallet JC, Baril G, Verdier M, Poulin N, Legendre $X$, Mermillod P: Successful use of oviduct epithelial cell coculture for in vitro production of viable red deer (Cervus elaphus) embryos. Theriogenology 2005, 64:1729-1739.

14. Khatir H, Anouassi A, Tibary A: Production of dromedary (Camelus dromedarius) embryos by IVM and IVF and co-cul- ture with oviductal or granulosa cells. Theriogenology 2004 62: $1175-1185$.

15. Coy P, Cánovas S, Mondéjar I, Saavedra MD, Romar R, Grullón L, Matás C, Avilés M: Oviduct-specific glycoprotein and heparin modulate sperm-zona pellucida interaction during fertilization and contribute to the control of polyspermy. Proc Natl Acad Sci USA 2008, 105:15809-I58|4.

16. O'Day-Bowman MB, Mavrogianis PA, Reuter LM, Johnson DE, Fazleabas AT, Verhage HG: Association of oviduct-specific glycoproteins with human and baboon (Papio anubis) ovarian oocytes and enhancement of human sperm binding to human hemizonae following in vitro incubation. Biol Reprod 1996, 54:60-69.

17. Hao Y, Mathialagan N, Walters E, Mao J, Lai L, Becker D, Li W, Critser J, Prather RS: Osteopontin reduces polyspermy during in vitro fertilization of porcine oocytes. Biol Reprod 2006, 75:726-733

18. Gonçalves RF, Chapman DA, Bertolla RP, Eder I, Killian G]: Pretreatment of cattle semen or oocytes with purified milk osteopontin affects in vitro development. Anim Reprod Sci 2008, 108:375-383.

19. Monaco E, Gasparrini B, Boccia L, De Rosa A, Attanasio L, Zicarelli L, Killian G: Effect of osteopontin (OPN) on in vitro embryo development in cattle. Theriogenology 2009, 71:450-457.

20. Anderson RA, Feathergill KA, Drisdel RC, Rawlins RG, Mack SR, Zaneveld L): Atrial Natriuretic peptide (ANP) as a stimulus of the human accrosome reaction and a component of ovarian follicular fluid: correlation of follicular ANP content with in vitro fertilization outcome. I Androl 1994, 1 5:61-70.

21. Zamir N, Barkan D, Keynan N, Naor Z, Breitbart H: Atrial Natriuretic peptide induces acrosomal exocytosis in bovine spermatozoa. Am J Physiol 1995, 269:E2 I6-E22I.

22. Zhang M, Hong H, Zhou B, Jin S, Wang C, Fu M, Wang S, Xia G: The expression of atrial natriuretic peptide in the oviduct and its functions in pig spermatozoa. J Endocrinol 2006, 189:493-507.

23. Buhi WC: Characterization and biological roles of oviductspecific, oestrogen-dependent glycoprotein. Reproduction 2002, I 23:355-362.

24. Palmer E, Bézard J, Magistrini M, Duchamp G: In vitro fertilization in the horse. A retrospective study. J Reprod Fertil I991, 44(Suppl):375-384.

25. Dell'Aquila ME, Fusco S, Lacalandra GM, Maritato F: In vitro maturation and fertilization of equine oocytes recovered during the breeding season. Theriogenology 1996, 45:547-560.

26. Alm H, Torner H, Blottner S, Nürnberg G, Kanitz W: Effect of sperm cryopreservation and treatment with calcium ionophore or heparin on in vitro fertilization of horse oocytes. Theriogenology 2001, 56:817-829.

27. McPartlin LA, Suarez SS, Czaya CA, Hinrichs K, Bedford-Guaus SJ: Hyperactivation of stallion sperm is required for successful in vitro fertilization of equine oocytes. Biol Reprod 2009, 81:199-206.

28. Abeydeera LR, Day BN: Fertilization and subsequent development in vitro of pig oocytes inseminated in a modified trisbuffered medium with frozen-thawed ejaculated spermatozoa. Biol Reprod 1997, 57:729-734.

29. Funahashi H, Day BN: Advances in in-vitro production of porcine embryos. J Reprod Fertil 1997, 52(SuppI):27I-283.

30. Day BN: Reproductive biotechnologies: current status in porcine reproduction. Anim Reprod Sci 2000, 60-61:161-172.

31. Nagai T, Funahashi H, Yoshioka K, Kikuchi K: Up date of in vitro production of porcine embryos. Front Biosci 2006, I I :2565-2573.

32. Hashimoto S: Application of in vitro maturation to assisted reproductive technology. J Reprod Dev 2009, 55: I-I0.

33. Crozet N, Ahmed-Ali M, Dubos MP: Developmental competence of goat oocytes from follicles of different size categories following maturation, fertilization and culture in vitro. J Reprod Fertil 1995, 103:293-298.

34. Keskintepe L, Darwish GM, Kenimer AT, Brackett BG: Term development of caprine embryos derived from immature oocytes in vitro. Theriogenology 1994, 42:527-35.

35. Rho GJ, Hahnel AC, Betteridge KJ: Comparisons of oocyte maturation times and of three methods of sperm preparation for their effects on the production of goat embryos in vitro. Theriogenology 200I, 56:503-516.

36. Katska-Ksiazkiewicz L, Ryñska B, Gajda B, Smorag Z: Effect of donor stimulation, frozen semen and heparin treatment on 
the efficiency of in vitro embryo production in goats. Theriogenology 2004, 62:576-586.

37. Crozet $N$, Huneau $D$, Desmedt $V$, Théron $M C$, Szöllösi $D$, Torrès $S$, Sévellec C: In vitro fertilization with normal development in the sheep. Gamete Res 1987, 16:159-170.

38. Wan PC, Hao ZD, Zhou P, Wu Y, Yang L, Cui MS, Liu SR, Zeng SM: Effects of SOF and CRI media on developmental competence and cell apoptosis of ovine in vitro fertilization embryos. Anim Reprod Sci 2009, I | 4:279-288.

39. Ellington JE, Ball BA, Yang X: Binding of stallion spermatozoa to the equine zona pellucida after coculture with oviductal epithelial cells. J Reprod Fertil 1993, 98:203-208.

40. Ellington JE, Samper JC, Jones AE, Oliver SA, Burnett KM, Wright $R W$ : In vitro interactions of cryopreserved stallion spermatozoa and oviduct (uterine tube) epithelial cells or their secretory products. Anim Reprod Sci 1999, 56:5I-65.

4I. Dobrinski I, Suarez SS, Ball BA: Intracellular calcium concentration in equine spermatozoa attached to oviductal epithelial cells in vitro. Biol Reprod 1996, 54:783-788.

42. Dobrinski I, Smith TT, Suarez SS, Ball BA: Membrane contact with oviductal epithelium modulates the intracellular calcium concentration of equine spermatozoa in vitro. Biol Reprod 1997, 56:86|-869.

43. Thomas PG, Ball BA, Brinsko SP: Interaction of equine spermatozoa with oviduct epithelial cell explants is affected by estrous cycle and anatomic origin of explants. Biol Reprod 1994, 5 I:222-228.

44. Thomas PG, Ball BA, Miller PG, Brinsko SP, Southwood L: A subpopulation of morphologically normal, motile spermatozoa attach to equine oviduct epithelial cell monolayers. Biol Reprod 1994, 51:303-309.

45. Hinrichs K, Love CC, Brinsko SP, Choi YH, Varner DD: In vitro fertilization of in vitro-matured equine oocytes: effect of maturation medium, duration of maturation, and sperm calcium ionophore treatment, and comparison with rates of fertilization in vivo after oviductal transfert. Biol Reprod 2002, 67:256-262.

46. Deleuze S, Goudet G, Caillaud M, Lahuec C, Duchamp G: Efficiency of embryonic development after intrafollicular and intraoviductal transfer of in vitro and in vivo matured horse oocytes. Theriogenology 2009, 72:203-209.

47. Deleuze S, Dubois CS, Caillaud M, Bruneau B, Goudet G, Duchamp $G$ : Influence of cysteamine on in vitro maturation, in vitro and in vivo fertilization of equine oocytes. Reprod Domest Anim 2008 in press.

48. Duchamp G, Bour B, Combarnous Y, Palmer E: Alternative solutions to hCG induction of ovulation in the mare. J Reprod Fertil I 987, 35(Suppl):22 I-228.

49. Mugnier S, Boittin S, Douet C, Monget P, Magistrini M, Goudet G: The involvement of beta-I,4-Galactosyltransferase and $N$ Acetylglucosamine residues in fertilization has been lost in the horse. Reprod Biol Endocrinol 2008, 6:5I.

50. Goudet G, Belin F, Mlodawska W, Bezard J: Influence of Epidermal Growth Factor on in vitro maturation of equine oocytes. J Reprod Fertil 2000, I5(Suppl):49-52.

51. Mugnier S, Dell'Aquila ME, Pelaez J, Douet C, Ambruosi B, De Santis T, Lacalandra GM, Lebos C, Sizaret PY, Delaleu B, Monget P, Mermillod P, Magistrini M, Meyers SA, Goudet G: New insights into the mechanisms of fertilization: Comparison of the fertilization steps, composition, and structure of the zona pellucida between horses and pigs. Biol Reprod 2009, 81 1:856-870.

52. Magistrini M, Palmer E: Motility, triple stain and electron microscopic analysis of spermatozoa treated with ionophore A23187 for in vitro fertilization. J Reprod Fertil |99|, 44(Suppl):66I-663.

53. Goudet G, Bézard J, Duchamp G, Gérard N, Palmer E: Equine oocyte competence for nuclear and cytoplasmic in vitro maturation: effect of follicle size and hormonal environment. Biol Reprod 1997, 57:232-245.

54. Hubbard TJ, Aken BL, Ayling S, Ballester B, Beal K, Bragin E, Brent S, Chen Y, Clapham P, Clarke L, Coates G, Fairley S, Fitzgerald S, Fernandez-Banet J, Gordon L, Graf S, Haider S, Hammond M, Holland R, Howe K, Jenkinson A, Johnson N, Kahari A, Keefe D, Keenan S, Kinsella R, Kokocinski F, Kulesha E, Lawson D, Longden I, Megy K, Meidl P, Overduin B, Parker A, Pritchard B, Rios D, Schuster M, Slater G, Smedley D, Spooner W, Spudich G, Trevanion S, Vilella A, Vogel J,
White S, Wilder S, Zadissa A, Birney E, Cunningham F, Curwen V, Durbin R, Fernandez-Suarez XM, Herrero J, Kasprzyk A, Proctor G, Smith J, Searle S, Flicek P: Ensembl 2009. Nucleic Acids Res 2009:D690-7.

55. Altschul SF, Madden TL, Schäffer AA, Zhang J, Zhang Z, Miller W, Lipman D]: Gapped BLAST and PSI-BLAST: a new generation of protein database search programs. Nucleic Acids Res 1997, 25(17):3389-402

56. Birney E, Clamp M, Durbin R: GeneWise and Genomewise. Genome Res 2004, 14(5):988-995.

57. Jones DT, Taylor WR, Thornton JM: The rapid generation of mutation data matrices from protein sequences. Comput Appl Biosci 1992, 8:275-282.

58. Tamura K, Dudley J, Nei M, Kumar S: MEGA4: Molecular Evolutionary Genetics Analysis (MEGA) software version 4.0. Mol Biol Evol 2007, 24:1596-1599.

59. Martus NS, Verhage HG, Mavrogianis PA, Thibodeaux JK: Enhancement of bovine oocyte fertilization in vitro with a bovine oviductal specific glycoprotein. J Reprod Fertil 1998, I I 3:323-329.

60. Rizos D, Pintado B, de la Fuente J, Lonergan P, Gutiérrez-Adan A: Development and pattern of mRNA relative abundance of bovine embryos cultured in the isolated mouse oviduct in organ culture. Mol Reprod Dev 2007, 74:7। 6-723.

61. Ellington JE, Jones AE, Davitt CM, Schneider CS, Brisbois RS, Hiss GA, Wright RW: Human sperm function in co-culture with human, macaque or bovine oviduct epithelial cell monolayers. Hum Reprod 1998, 13:2797-2804

62. Petrunkina AM, Simon K, Günzel-Apel AR, Töpfer-Petersen E: Kinetics of protein tyrosine phosporylation in sperm selected by binding to homologous and heterologous oviductal explants: how specific is the regulation by the oviduct? Theriogenology 2004, 61:1617-1634.

63. Bézard J, Magistrini M, Duchamp G, Palmer E: Chronology of equine fertilization and embryonic development in vivo and in vitro. Equine Vet J 1989, 8(Suppl): I05-1 I0.

64. Laurincik J, Hyttel P, Rath D, Pivko J: Ovulation, fertilization and pronucleus development in superovulated gilts. Theriogenology 1994, 4 I:447-452.

65. Qian Y, Shi WQ, Ding JT, Liu JY, Sha JH, Fan BQ: Effects of type and state of co-culture cells on in-vitro development of porcine oocytes matured and fertilized in vitro. J Assist Reprod Genet 2005, 22:233-238.

66. Wegner CC, Killian GJ: In vitro and in vivo association of an oviduct estrus-associated protein with bovine zona pellucida. Mol Reprod Dev 1991, 29:77-84.

67. Buhi WC, O'Brien B, Alvarez IM, Erdos G, Dubois D: Immunogold localization of porcine oviductal secretory proteins within the zona pellucida, perivitelline space, and plasma membrane of oviductal and uterine oocytes and early embryos. Biol Reprod 1993, 48: 1274-I283.

68. Gonçalves RF, Staros AL, Killian GJ: Oviductal fluid proteins associated with the bovine zona pellucida and the effect on in vitro sperm-egg binding, fertilization and embryo development. Reprod Domest Anim 2008, 43:720-729.

69. Familiari G, Heyn R, Relucenti M, Sathananthan H: Structural changes of the zona pellucida during fertilization and embryo development. Front Biosci 2008, 13:6730-675I.

70. Kidson A, Schoevers E, Langendijk P, Verheijden J, Colenbrander B, Bevers $M$ : The effect of oviductal epithelial cell co-culture during in vitro maturation on sow oocyte morphology, fertilization and embryo development. Theriogenology 2003, 59:1889-1903.

7I. Romar R, Coy P, Gadea J, Rath D: Effect of oviductal and cumulus cells on zona pellucida and cortical granules of porcine oocytes fertilized in vitro with epididymal spermatozoa. Anim Reprod Sci 2005, 85:287-300.

72. Wang WH, Abeydeera LR, Okuda K, Niwa K: Penetration of porcine oocytes during maturation in vitro by cryopreserved, ejaculated spermatozoa. Biol Reprod 1994, 50:510-515.

73. Wongsrikeao P, Kaneshige Y, Ooki R, Taniguchi M, Agung B, Nii M, Otoi T: Effect of the removal of cumulus cells on the nuclear maturation, fertilization and development of porcine oocytes. Reprod Domest Anim 2005, 40:166-170.

74. Romar R, Coy P, Ruiz S, Gadea J, Rath D: Effects of oviductal and cumulus cells on in vitro fertilization and embryo develop- 
ment of porcine oocytes fertilized with epididymal spermatozoa. Theriogenology 2003, 59:975-986.

75. Fatehi AN, Zeinstra EC, Kooij RV, Colenbrander B, Bevers MM: Effect of cumulus cell removal of in vitro matured bovine oocytes prior to in vitro fertilization on subsequent cleavage rate. Theriogenology 2002, 57:1347-1355.

76. Thomas WK, Seidel GE: Effects of cumulus cells on culture of bovine embryos derived from oocytes matured and fertilized in vitro. J Anim Sci 1993, 71:2506-2510.

77. Abe $H$, Hoshi $H$ : Regional and cyclic variations in the ultrastructual features of secretory cells in the oviductal epithelium of the Chinese Meishan pig. Reprod Domest Anim 2007 42:292-298.

78. Xia P, Rutledge J, Watson AJ, Armstrong DT: Effect of estrogentreated porcine ampulla oviductal epithelial cells on early embryonic development in vitro and characterization of their protein synthetic activity. Anim Reprod Sci 1996, 45:217-229.

79. Sun T, Lei ZM, Rao CV: A novel regulation of the oviductal glycoprotein gene expression by luteinizing hormone in bovine tubal epithelial cells. Mol Cell Endocrinol 1997, 131:97-108.

80. Mishra S, Lei ZM, Rao ChV: A novel role of luteinizing hormone in the embryo development in cocultures. Biol Reprod 2003, 68: $1455-1462$

8I. Gawronska B, Paukku T, Huhtaniemi I, Wasowicz G, Ziecik AJ: Oestrogen-dependent expression of LH/hCG receptors in pig Fallopian tube and their role in relaxation of the oviduct. J Reprod Fertil 1999, I 15:293-301.

82. Gawronska B, Stepien A, Ziecik AJ: Effect of estradiol and progesterone on oviductal $\mathbf{L H}$-receptors and $\mathrm{LH}$-dependent relaxation of the porcine oviduct. Theriogenology 2000, 53:659-672.

83. Grondahl C, Host T, Brück I, Viuff D, Bézard J, Fair T, Greve T, Hyttel P: In vitro production of equine embryos. Biol Reprod 1995, I(Mono):299-307.

84. Brown LF, Berse B, Water L Van de, Papadopoulos-Sergiou A, Perruzzi CA, Manseau EJ, Dvorak HF, Senger DR: Expression and distribution of osteopontin in human tissues: widespread association with luminal epithelial surfaces. Mol Biol Cell 1992, 3:1169-1180.

85. Gabler C, Chapman DA, Killian G]: Expression and presence of osteopontin and integrins in the bovine oviduct during the oestrous cycle. Reproduction 2003, I 26:72 I-729.

86. Tian X, Pascal G, Fouchécourt S, Pontarotti P, Monget P: Gene birth, death, and divergence: the different scenarios of reproduction-related gene evolution. Biol Reprod 2009, 80:616-62|.

87. Verhage HG, Mavrogianis PA, O'Day-Bowman MB, Schmidt A, Arias EB, Donnelly KM, Boomsma RA, Thibodeaux JK, Fazleabas AT, Jaffe RC: Characteristics of an oviductal glycoprotein and its potential role in the fertilization process. Biol Reprod 1998, 58:1098-II0I.

88. Kim SH, Cho KW, Kim SZ, Koh GY: Characterization of the atrial natriuretic peptide system in the oviduct. Endocrinology 1997, 138:2410-2416.

89. Rotem R, Zamir N, Keynan N, Barkan D, Breitbart H, Naor Z: Atrial natriuretic peptide induces acrosomal exacytosis of human spermatozoa. Am J Physiol 1998, 274:218-223.

90. Bauersachs S, Blum H, Mallok S, Wenigerkind H, Rief S, Prelle K, Wolf $\mathrm{E}$ : Regulation of ipsilateral and contralateral bovine oviduct epithelial cell function in the postovulation period: a transcriptomics approach. Biol Reprod 2003, 68: I 170-1177.

91. Bauersachs S, Rehfeld S, Ulbrich SE, Mallok S, Prelle K, Wenigerkind $\mathrm{H}$, Einspanier R, Blum $\mathrm{H}$, Wolf $\mathrm{E}$ : Monitoring gene expression changes in bovine oviduct epithelial cells during the oestrous cycle. J Mol Endocrinol 2004, 32:449-466.

92. Georgiou AS, Snijders AP, Sostaric E, Aflatoonian R, Vazquez JL, Vazquez JM, Roca J, Martinez EA, Wright PC, Fazeli A: Modulation of the oviductal environment by gametes. J Proteome Res 2007, 6:4656-4666.

93. Carrasco LC, Romar R, Avilés M, Gadea J, Coy P: Determination of glycosidase activity in porcine oviductal fluid at the different phases of the estrous cycle. Reproduction 2008, I36:833-842.

94. Cooper MA: Optical biosensors in drug discovery. Nat Rev Drug Discov 2002, 1:515-28.

95. Rich RL, Myszka DG: A survey of the year 2002 commercial optical biosensor literature. J Mol Recognit 2003, 16:35I-382.
Publish with Biomed Central and every scientist can read your work free of charge

"BioMed Central will be the most significant development for disseminating the results of biomedical research in our lifetime. "

Sir Paul Nurse, Cancer Research UK

Your research papers will be:

- available free of charge to the entire biomedical community

- peer reviewed and published immediately upon acceptance

- cited in PubMed and archived on PubMed Central

- yours - you keep the copyright

Submit your manuscript here:

http://www.biomedcentral.com/info/publishing_adv.asp 